\title{
Inclusion of exogenous enzymes to feathers during processing on the digestible energy content of feather meal for adult dogs
}

\section{Gabriel Faria Estivallet Pacheco언 Júlia Guazzelli Pezzali², Alexandre de Mello Kessler ${ }^{3}$, Luciano Trevizan ${ }^{3}$}

\footnotetext{
1 Universidade Federal do Rio Grande do Sul, Programa de Pós-graduação em Zootecnia, Porto Alegre, RS, Brazil.

${ }^{2}$ Universidade Federal do Rio Grande do Sul, Faculdade de Medicina Veterinária, Porto Alegre, RS, Brazil.

${ }^{3}$ Universidade Federal do Rio Grande do Sul, Departamento de Zootecnia, Porto Alegre, RS, Brazil.
}

\begin{abstract}
This study was conducted to determine the coefficient of total tract apparent digestibility (CTTAD) of nutrients and gross energy (GE), metabolizable energy (ME), coefficient of metabolizability of gross energy (CM of GE), and fecal characteristics of dogs fed diets with two levels of feather meal, with or without addition of an enzyme blend containing lipase and protease activity. Ten adult Beagle dogs (aged between 1 and 2 years and weighing $10.2 \pm 1.4 \mathrm{~kg}$ ) were arranged in a $5 \times 3$ incomplete Latin square design with five treatments and three periods. The extruded basal diet was provided in equal amounts to all dogs $(220 \mathrm{~g} / \mathrm{d})$, and 7.5 and $15 \%$ of hydrolyzed feather meal without enzymes (HFM) or HFM processed with addition of the enzyme blend (HFM EB) was added on top of the basal diet just before feeding. The contrast analysis showed that inclusion of 7.5 or $15 \%$ feather meal negatively affected CTTAD of crude protein (CP), GE, and ME of the diets with no apparent effect of the enzyme treatment. However, when both feather meal samples were evaluated, the HFM EB resulted in better CTTAD of GE and CM of GE (0.774 vs. 0.666) than HFM without enzymes (0.670 vs. 0.567), respectively. There was no effect of either feather meal on fecal score. Regression analysis showed that the enzymes added to the feathers during the digestion process increased digestible energy by $600 \mathrm{kcal} / \mathrm{kg}$ of dry matter in the diet containing HFM EB. High-performance liquid chromatography (HPLC) analysis demonstrated that feather meal had a low molecular weight, with about $95 \%$ of the molecules below 10,000 Da. Addition of enzymes during the feather hydrolysis process may improve the energy content of the feather meal when included in diets for adult dogs.
\end{abstract}

Key Words: by-product, digestibility, lipase, protease, protein source

\section{Introduction}

The demand for quality sources of protein is likely to increase in coming years, which may lead to greater competition between humans and animals for quality sources of amino acids (Chiba, 2001), especially due to the increasing global population, which is estimated to reach about 9 billion by 2050 (Bongaarts, 2009). Clearly, it is important to find alternative sources of protein for sustainable animal nutrition. Inclusion of feather meal in dog diets has been associated with low-quality diets (Murray et al., 1997). However, hydrolyzed feather meal (HFM) may be a low-cost source of protein to be included in diets for poultry, pigs, dogs, and cats. Although the biological value of feather meal is lower for non-ruminants, it provides indispensable amino acids to the diet (Yin et al., 1993; Ssu et al., 2004).

Received November 4, 2015 and accepted March 17, 2016.

Corresponding author: gfepacheco@hotmail.com

http://dx.doi.org/10.1590/S1806-92902016000600002

Copyright (C) 2016 Sociedade Brasileira de Zootecnia. This is an Open Access article distributed under the terms of the Creative Commons Attribution License (http://creativecommons.org/licenses/by/4.0/), which permits unrestricted use, distribution, and reproduction in any medium, provided the original work is properly cited.
Feathers should be processed in batch cookers with high temperatures and pressures to disrupt the structure of keratin in the feathers, thus making the proteins available to animal digestion and absorption. However, the exposure of feathers to these conditions for a long time may have a negative effect on the availability of amino acids, which are sensitive to temperature (Johnson et al., 1998; Considine, 2000). The addition of exogenous enzymes to the batch cooker, associated with low-temperature and low-pressure processing, has been one of the alternatives used to mitigate effects of overheating the feather meal, improving the quality of the end product and saving energy (Pedersen et al., 2012).

Unfortunately, nutrient digestibility data for feather meal in dog diets are rather limited. However, because feather meal is an ingredient commonly included in lowcost diets for dogs, the improvement in energy digestibility in feather meal is expected to increase the quality of those diets. Therefore, the present study investigated the effect of adding enzymes during feather processing on digestibility of nutrients, metabolizable energy (ME) content, and fecal characteristics when included in diets of adult dogs. 


\section{Material and Methods}

The experimental protocol used in this study was approved by the Ethics Committee on Animal Use of Universidade Federal do Rio Grande do Sul (case no. 20643), and the experiment was conducted in accordance with ethical and animal welfare guidelines.

A total of ten adult Beagle dogs, five males and five females, not neutered, between 1 and 2 years old, weighing $10.2 \pm 1.4 \mathrm{~kg}$, with a body condition score $5 \pm 1$ of 9 (Laflamme, 1997), were used to test the basal diet and diets containing feather meal that had undergone different processing methods. Before the experiment was started, the healthy dogs were assessed by complete blood counts, biochemical indices (glucose, cholesterol, triglycerides, urea, and creatinine) and coproparasitological analysis. All dogs were vaccinated and considered healthy. During the digestibility assay, dogs were kept in stainless steel metabolic cages $(80 \mathrm{~cm} \times 70 \mathrm{~cm} \times 90 \mathrm{~cm})$ equipped with an apparatus to collect and separate feces and urine, as well as a feeder and water drinkers, in a temperature-controlled room at $24{ }^{\circ} \mathrm{C}$ with a $14 \mathrm{~h}$ light: $10 \mathrm{~h}$ dark cycle.

A nutritionally balanced basal diet was formulated and extruded without any poultry by-product. The ingredient feather meal was subjected to different processes: conventional or enzymatic hydrolysis (Table 1 and Figure 1). The hydrolyzed feather meal without enzyme blend (HFM) was produced in a conventional manner: fresh feathers $(2,200 \mathrm{~kg})$ and blood $(1,600 \mathrm{~kg})$ were added to the batch cooker simultaneously, followed by steam injection at $110{ }^{\circ} \mathrm{C}$ for $20 \mathrm{~min}$. The hydrolysis was started by raising the temperature to $160{ }^{\circ} \mathrm{C}$ and pressure to $300 \mathrm{kPa}$ for $40 \mathrm{~min}$. Afterwards, the HFM was dried for $75 \mathrm{~min}$, milled through a $5 \mathrm{~mm}$ sieve, and bagged.

The HFM that was processed with the enzyme blend (HFM EB) was produced by adding the same amount of feather and blood into the batch cooker used to compose
HFM. The enzyme-treated HFM was produced by Aspergillus niger and consisted of 130 lipase units (LU)/g and 12,500 hemoglobin units tyrosine base (HUT)/g (Allzyme FD; Alltech Intl.). One LU activity is defined as the quantity of enzyme that will liberate one micromole of butyric acid per minute under the test conditions. One HUT base activity is defined as that amount of enzyme that produces, in 1 minute under the specified conditions, a hydrolyzate

Table 1 - Chemical composition $(\mathrm{g} / \mathrm{kg})$, pepsin digestibility, and analyzed molecular weight of both feather meal samples

\begin{tabular}{|c|c|c|}
\hline Item & HFM & HFM EB \\
\hline \multicolumn{3}{|l|}{ Analyzed composition } \\
\hline Dry matter & 928 & 966 \\
\hline Crude protein & 753 & 802 \\
\hline Arginine & 52.3 & 52.1 \\
\hline Histidine & 12.8 & 11.6 \\
\hline Isoleucine & 34.0 & 36.1 \\
\hline Leucine & 62.2 & 63.0 \\
\hline Lysine & 27.5 & 25.4 \\
\hline Methionine & 7.9 & 7.5 \\
\hline Cysteine & 26.8 & 35.5 \\
\hline Phenylalanine & 37.2 & 37.9 \\
\hline Tyrosine & 22.7 & 23.0 \\
\hline Threonine & 35.2 & 36.9 \\
\hline Valine & 50.0 & 53.4 \\
\hline Alanine & 41.0 & 37.4 \\
\hline Aspartic acid & 52.4 & 54.1 \\
\hline Glutamic acid & 87.4 & 86.7 \\
\hline Glycine & 55.7 & 55.6 \\
\hline Proline & 60.9 & 64.3 \\
\hline Serine & 68.9 & 73.8 \\
\hline Ether extract & 116 & 126 \\
\hline Gross energy, $\mathrm{kcal} / \mathrm{kg}$ & 5,502 & 5,710 \\
\hline Pepsin digestibility $0.02 \%$ & 598 & 583 \\
\hline \multicolumn{3}{|c|}{ Analyzed protein molecular weight, $\%$} \\
\hline$>20,000 \mathrm{Da}$ & 0.30 & 0.30 \\
\hline $20,000-10,000 \mathrm{Da}$ & 4.40 & 3.50 \\
\hline $10,000-5,000 \mathrm{Da}$ & 14.7 & 11.9 \\
\hline $5,000-1,000 \mathrm{Da}$ & 25.2 & 21.8 \\
\hline $1,000-500 \mathrm{Da}$ & 5.00 & 4.50 \\
\hline$<500 \mathrm{Da}$ & 50.4 & 58.0 \\
\hline
\end{tabular}

HFM - hydrolyzed feather meal; HFM EB - hydrolyzed feather meal with enzyme blend containing protease and lipase (Allzyme FD; Alltech Intl.).

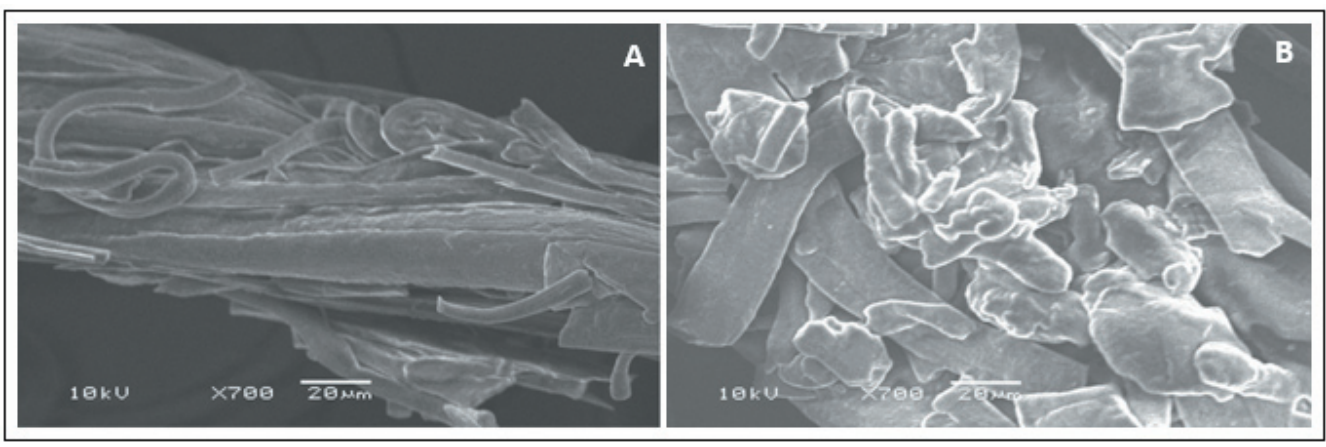

Figure 1 - Scanning electron micrographs of hydrolyzed feather meal (A) and hydrolyzed feather meal processed with an enzyme blend containing proteases and lipases (B). 
whose absorbance at $275 \mathrm{~nm}$ is the same as one solution containing $1.10 \mu \mathrm{g} / \mathrm{mL}$ of tyrosine in $0.006 \mathrm{~N}$ hydrochloric acid. Enzymes were added at $0.5 \mathrm{~kg}$ per ton of fresh material, as well as sodium metabisulfite $(2.5 \mathrm{~kg} / \mathrm{t})$ diluted in $10 \mathrm{~L}$ of water. The batch cooker temperature was maintained at $32{ }^{\circ} \mathrm{C}$ for addition of ingredients. After addition of all ingredients, the batch cooker was closed and the hydrolysis was started.

The pre-digestion period was the time ( $40 \mathrm{~min}$ ) between adding the first bucket of the enzymes and the closure of the batch cooker. The batch cooker temperature was raised from $32{ }^{\circ} \mathrm{C}$ to $110^{\circ} \mathrm{C}$, and the pressure was raised to $200 \mathrm{kPa}$ for $40 \mathrm{~min}$. Upon completion of cooking, the batch cooker was depressurized, and feathers were dried for $75 \mathrm{~min}$, milled through a $5 \mathrm{~mm}$ sieve, and bagged.

The test diets were made from a basal diet including HFM or HFM EB. Both types of feather meals were well accepted by the dogs, and they were added on top of basal diet in the feeder prior to offering the diets to the dogs. Besides the basal diet, four treatments were offered, represented by different levels of inclusion of feather meal ( 7.5 or $15 \%$ of the basal diet), processed, or not, with enzymes. The treatments consisted of: basal diet $=$ control diet (diet without feather meal); HFM $7.5=$ basal diet + $7.5 \%$ HFM without EB; HFM EB $7.5=$ basal diet $+7.5 \%$ HFM EB; HFM 15 = basal diet $+15 \%$ HFM without EB; and HFM EB 15 = basal diet $+15 \%$ HFM EB (Table 2). The basal diet was coated with $1 \%$ chicken fat to enhance palatability.

The extruded basal diet was provided in equal amounts to all dogs $(220 \mathrm{~g} /$ day $)$, and was increased by $0,16.5 \mathrm{~g}(6.8 \%$ DM basis), or $33 \mathrm{~g}$ (13\% DM basis) of HFM or HFM EB to compose the treatments, according to the methodology described by Adeola (2001). Thus, different groups of dogs received $220 \mathrm{~g}$ of basal diet, $236.5 \mathrm{~g}$ of HFM 7.5 or HFM EB 7.5 diet, and 253 g HFM 15 or HFM EB 15 diet. The daily amount of food was divided into two equal meals at $08.00 \mathrm{~h}$ and $17.00 \mathrm{~h}$ to provide enough food to meet the energy needs of adult dogs as recommended by NRC (2006). Dogs had free access to water throughout the experiment.

The experimental design was a $5 \times 3$ incomplete Latin square design consisting of five treatments and three periods, two dogs per treatment in each period, and thus six replicate dogs per treatment (Ai et al., 2013; Jeong et al., 2015). The periods lasted 15 days, with five days for adaptation to the cage and experimental diet, followed by five days of total feces and urine collection to determine digestibility, according to the recommendations of AAFCO (2008). A rest period of five days was provided between each period in which dogs were stimulated to play with caretakers.

Total feces collection was performed throughout the days and evaluated for consistency by subjective evaluation of fecal score according to the following scale: 1 = watery: liquid that can be poured; 2 = soft: formless stool that assumes shape of container; 3 = soft, formed, and moist: softer stool that retains shape; $4=$ hard, formed, and dry stool: remains firm and smooth; and 5 = hard: dry pellet. Total feces were collected at least twice daily, weighed, and frozen $\left(-18^{\circ} \mathrm{C}\right)$ until analysis. Urine total collections were taken daily in plastic containers under the gutter, containing $1 \mathrm{~mL}$ of sulfuric acid $\left(\mathrm{H}_{2} \mathrm{SO}_{4}\right) 1 \mathrm{Eq} / \mathrm{L}(1 \mathrm{~N})$ to lower the $\mathrm{pH}$ to $<5$ (Adeola, 2001) and to prevent nitrogen loss according to AAFCO (2008). The total volume of urine was measured and urine was frozen $\left(-18{ }^{\circ} \mathrm{C}\right)$ until analysis.

At the end of the sampling periods, feces and urine from each dog were thawed, homogenized, and dried in a forced-air oven at a temperature of $55{ }^{\circ} \mathrm{C}$ for $72 \mathrm{~h}$ as recommended by AOAC (2005). Feces and diets were ground through a $1 \mathrm{~mm}$ screen using a Wiley hammer mill (DeLeo Equipamentos Laboratoriais, Porto Alegre, Brazil), and analyzed for DM (method 934.01), ash (method 942.05), and CP (method 954.01; model TE 036/2, Tecnal, Piracicaba, Brazil). The acid-hydrolyzed fat (method 954.02; model 170/3, Fanem, São Paulo, Brazil) was analyzed only in the diets. Urine samples were analyzed

Table 2 - Ingredients and chemical composition of experimental diets $(\mathrm{g} / \mathrm{kg}$ diet $)$

\begin{tabular}{lccccc}
\hline & \multicolumn{5}{c}{ Treatment } \\
\cline { 2 - 6 } Item & Basal & HFM & HFM & HFM & HFM \\
& diet & 7.5 & EB 7.5 & 15 & EB 15 \\
\hline Ingredient (g/kg, as-fed basis) & & & & & \\
Whole rice bran & 304.0 & 282.0 & 282.0 & 264.0 & 264.0 \\
Broken rice & 308.0 & 286.0 & 286.0 & 268.0 & 268.0 \\
Meat and bone meal & 177.0 & 165.0 & 165.0 & 154.0 & 154.0 \\
Wheat bran & 101.0 & 94.9 & 94.9 & 88.3 & 88.3 \\
Defatted rice bran & 91.1 & 84.7 & 84.7 & 79.2 & 79.2 \\
Poultry fat & 9.9 & 9.2 & 9.2 & 8.6 & 8.6 \\
Salt & 5.0 & 4.7 & 4.7 & 4.4 & 4.4 \\
Premix mineral/vitamin ${ }^{1}$ & 4.0 & 3.7 & 3.7 & 3.5 & 3.5 \\
Hydrolyzed feather meal & 0 & 69.8 & 69.8 & 130.0 & 130.0 \\
& & & & & \\
Analyzed composition & 906 & 909 & 916 & 917 & 910 \\
Dry matter & 200 & 233 & 243 & 271 & 284 \\
Crude protein & 96.0 & 88.6 & 95.3 & 87.1 & 88.4 \\
Mineral matter & 118 & 120 & 121 & 115 & 121 \\
Acid-hydrolyzed fat & 4,747 & 4,845 & 4,939 & 4,905 & 4,899 \\
Gross energy, kcal/kg & & & & & \\
\hline
\end{tabular}

HFM - hydrolyzed feather meal; HFM EB - hydrolyzed feather meal with enzyme blend (protease and lipase).

${ }^{1}$ Provided per kilogram of diet: vitamin A - 9,000 IU; vitamin D3 - 800 IU; vitamin E - $50 \mathrm{mg}$; vitamin $\mathrm{K} 3$ - $4 \mathrm{mg}$; thiamine - $7 \mathrm{mg}$; riboflavin - $5 \mathrm{mg}$; pyridoxine - $5 \mathrm{mg}$; vitamin B12 - $25 \mathrm{mcg}$; pantothenate - $10 \mathrm{mg}$; nicotinic acid - $50 \mathrm{mg}$; folic acid - $1 \mathrm{mg}$; biotin - $70 \mathrm{mcg}$; $\mathrm{Zn}$ as zinc sulfate - $100 \mathrm{mg}$; Fe as ferrous sulfate $-80 \mathrm{mg}$; $\mathrm{Cu}$ as copper sulfate - $7 \mathrm{mg}$; I as calcium iodate - $1.5 \mathrm{mg}$; Se as sodium selenite - $0.3 \mathrm{mg}$; and $\mathrm{Mn}$ as manganese sulfate $-5 \mathrm{mg}$. 
for DM and CP. The GE in samples of food, feces, and urine was determined using an isoperibol bomb calorimeter (model C2000 basic, Ika-Werke, Staufen, Germany). The protein molecular weight analysis of both types of feather meal was performed by HPLC with an ultraviolet detector according to the methodology used by Kosińska et al. (2006). All analyses were performed in duplicate assuming the standard error between replicates of less than $5 \%$ for all methods and less than $1 \%$ for energy.

Data were analyzed using the ANOVA procedure of SAS (Statistical Analysis System, version 9.0). Preplanned contrasts (basal diet vs. feather meal, HFM vs. HFM EB, and diets HFM and HFM EB 7.5 vs. diets HFM and HFM EB 15) were conducted. Digestibility of feathers meal data were subjected to a $2 \times 2$ factorial analysis, considering the level of inclusion of both feather meals as factors. Nutrient and energy availability in feather meal were analyzed by regression analysis.

The coefficients of total tract apparent digestibility (CTTAD) of DM, OM, CP, and GE for HFM and HFM EB were calculated (Adeola, 2001). To calculate the digestible energy (DE) and ME of both feather meals, the digestible nutrients ingested by the dogs were taken into account. Digestible nutrients values obtained for treatments subtracted from the digestible nutrients in the basal diet (without feather meals) represented the digestible nutrients from the feather meal alone. This value divided by the actual consumption of the nutrient from the feather meal, multiplied by 100 , resulted in the nutrient CTTAD and energy digestibility of feather meal.

\section{Results and Discussion}

The feather meals were well accepted by the dogs that readily consumed them even as a pure source. All dogs consumed the total amount of the food offered. Foods were provided based on basal diet consumed by the control group. Contrast analysis demonstrated that with increasing inclusion of feather meal, the CTTAD and CM of GE of the diets decreased (Table 3$)(\mathrm{P}<0.05)$.

Fecal scores remained within the range from 3.5 to 4.5 and were considered "ideal" for both feather meals tested at both levels of inclusion (Case et al., 2011). The inclusion of HFM and HFM EB in the diets had no significant effect on fecal score or fecal DM. Greater volume of feces was produced by the dogs fed $15 \%$ of both feather meals.

The CTTAD of GE and the ME were reduced by the inclusion of feathers. This effect may be due to the limited capacity of the gastrointestinal tract to digest the HFM due to the buffering effect of the protein when 15\% HFM in the basal diet was consumed. It was expected that the greater inclusion could surpass the capacity of dogs to digest and absorb the nutrients from the feather meal included in the diet. The inter-chain disulfide bonds in the keratin structure result in low solubility of feather meal and great resistance to digestive enzymes, such as pepsin and trypsin, in nonruminant animals (Grazziotin et al., 2006). Another factor affecting ME of feathers is their amino acid profile: feather meal is relatively low in lysine and some other amino acids (AA); therefore, it must be incorporated into diets based on the AA balance (Sulabo et al., 2013). The imbalance among

Table 3 - Nutrient intake, coefficient of total tract apparent digestibility, metabolizable energy, and fecal characteristics of dogs fed diets containing 7.5 or $15 \%$ of hydrolyzed feather meal processed without (HFM) or with enzyme blend (HFM EB)

\begin{tabular}{|c|c|c|c|c|c|c|c|c|c|}
\hline \multirow[b]{2}{*}{ Item } & \multicolumn{5}{|c|}{ Treatment } & \multirow[b]{2}{*}{ SEM } & \multicolumn{3}{|c|}{ Contrast } \\
\hline & $\begin{array}{c}\text { Basal } \\
\text { diet }\end{array}$ & $\begin{array}{c}\text { HFM } \\
7.5\end{array}$ & $\begin{array}{c}\text { HFM EB } \\
7.5\end{array}$ & $\begin{array}{c}\text { HFM } \\
15\end{array}$ & $\begin{array}{c}\text { HFM EB } \\
15\end{array}$ & & $\begin{array}{c}\text { Basal diet vs. } \\
\text { HFM }\end{array}$ & $\begin{array}{l}\text { HFM vs. } \\
\text { HFM EB }\end{array}$ & $\begin{array}{c}\text { HFM } 7.5 \text { vs. } \\
\text { HFM } 15\end{array}$ \\
\hline \multicolumn{10}{|l|}{ Daily nutrient intake (g/dog) } \\
\hline Dry matter & 200 & 215 & 215 & 229 & 229 & 4.07 & 0.001 & 0.974 & 0.001 \\
\hline Organic matter & 181 & 195 & 194 & 209 & 209 & 4.07 & 0.001 & 0.987 & 0.001 \\
\hline Crude protein & 39.5 & 49.8 & 52.9 & 62.6 & 62.4 & 3.24 & 0.001 & 0.552 & 0.001 \\
\hline Gross energy (kcal/kg) & 4,759 & 5,210 & 5,304 & 5,614 & 5,609 & 112 & 0.001 & 0.566 & 0.001 \\
\hline \multicolumn{10}{|c|}{ Coefficient of total tract apparent digestibility } \\
\hline Dry matter & 0.712 & 0.714 & 0.707 & 0.696 & 0.704 & 0.84 & 0.503 & 0.954 & 0.212 \\
\hline Organic matter & 0.765 & 0.763 & 0.756 & 0.748 & 0.753 & 0.73 & 0.247 & 0.873 & 0.217 \\
\hline Crude protein & 0.700 & 0.713 & 0.699 & 0.675 & 0.690 & 0.88 & 0.566 & 0.939 & 0.014 \\
\hline Gross energy & 0.758 & 0.762 & 0.758 & 0.736 & 0.746 & 0.67 & 0.304 & 0.627 & 0.009 \\
\hline Metabolizable energy (kcal/kg) & 3,433 & 3,506 & 3,560 & 3,369 & 3,395 & 29.4 & 0.475 & 0.184 & $<0.001$ \\
\hline \multicolumn{10}{|l|}{ Stool characteristics } \\
\hline Fecal score ${ }^{1}$ & 3.75 & 3.62 & 3.68 & 3.58 & 3.67 & 0.09 & 0.285 & 0.423 & 0.788 \\
\hline Fecal dry matter, $\%$ & 32.22 & 31.45 & 31.60 & 31.59 & 32.54 & 0.73 & 0.608 & 0.454 & 0.468 \\
\hline Feces g/d (as-is) & 180.0 & 195.8 & 199.7 & 221.7 & 208.6 & 7.35 & 0.004 & 0.538 & 0.026 \\
\hline Feces g/d (dry) & 57.83 & 61.42 & 62.96 & 69.68 & 67.73 & 1.87 & 0.001 & 0.914 & 0.002 \\
\hline
\end{tabular}

${ }^{1}$ Fecal score 1 (watery) - liquid that can be poured; 2 (soft) - formless stool that assumes shape of container; 3 (soft, formed, and moist) - softer stool that retains shape; 4 (hard, formed, and dry stool) - remains firm and smooth shape; and 5 (hard) - dry pellet. 
amino acids may result in increased urinary $\mathrm{N}$ excretion and, consequently, a reduction in ME.

Negative effects of feather meal on nutrient digestibility of dog food were reported by Murray et al. (1997) and Cavalari et al. (2006). In a study evaluating different sources of animal protein, Cavalari et al. (2006) reported that diets containing extruded feather meal had lower values for CTTAD of GE (0.798), CTTAD of DM (0.760), and CTTAD of CP $(0.823)$ than diets containing extruded fish meal (0.991, 0.852, and 0.919), extruded poultry byproduct meal $(0.912,0.881$, and 0.889$)$, poultry by-product meal $(0.876,0.867$, and 0.880$)$, and extruded meat meal $(0.807,0.878$, and 0.823$)$, respectively. The nutritional composition and nutrient availability of feather meal can vary widely between feeds available in the market, and this variability may be related to the type of processing (Wang and Parsons, 1997; Kim and Patterson, 2000; Tiwary and Gupta, 2012). Another important factor that contributes to the difference in nutritional composition of feather meal is the contamination with other chicken co-products, such as blood, legs, heads, and viscera, which may increase the fat and ash content of the meal (Kim and Patterson, 2000; Bertsch and Coello, 2005).

Currently, the most economical method for hydrolysis of feathers is by using high temperature and pressure in the batch cooking for a long time. The processing acts on the disulfide bonds, allowing proteolytic digestive enzymes to act on the keratin in the gastrointestinal tract with improvement in amino acid availability compared to that for fresh feathers (Bielorai et al., 1982). Moreover, protein denaturation by high temperatures causes complexation or destruction of the thermosensitive amino acid, especially cysteine (Grazziotin et al., 2006; Rebafka and Kulshrestha, 2009) and the formation of nutrients such as lysinoalanine and lanthionine (Kim and Patterson, 2000; Bertsch and Coello, 2005), resulting in an ingredient with high levels of $\mathrm{CP}$, but poor amino acid bioavailability.

Addition of enzymes to the digester, in association with low temperature and pressure, improves the nutritional quality of feather meal, providing greater content of essential AA for livestock (Considine, 2000; Tiwary and Gupta, 2012). It may increase the degree of keratin hydrolysis (Pedersen et al., 2012).

The results obtained in this study demonstrated that both types of feather meals had low protein molecular weight and about $95 \%$ of the molecules were smaller than $10,000 \mathrm{Da}$, and $60 \%$ were smaller than $500 \mathrm{Da}$.

The method described by Adeola (2001) allowed estimation of the CTTAD of nutrients and energy in both feather meals. The DE and ME of the feather meals processed with protease and lipase, in association with low temperature and pressure, was greater $(\mathrm{P}<0.05)$ than those found in HFM, indicating some efficiency of the enzymes that were added to the batch cooker (Table 4).

Regression equations were used to estimate the relationship between the addition of HFM and HFM EB on DE of the total diet consumed (Figure 2). Based on the equations, the enzymes released about $600 \mathrm{kcal} \mathrm{DE} / \mathrm{kg} \mathrm{DM}$ from the feathers. The equations were most appropriate to evaluate the enzymatic action, and they imply that digestive enzymes were more likely to provide energy from feather meals processed with enzymes. The DE estimated for the HFM EB was $3,853 \mathrm{kcal} / \mathrm{kg}$ DM compared with $3,242 \mathrm{kcal} / \mathrm{kg}$ DM of HFM (Figure 2). Presumably, most of this energy was released from the protein, because

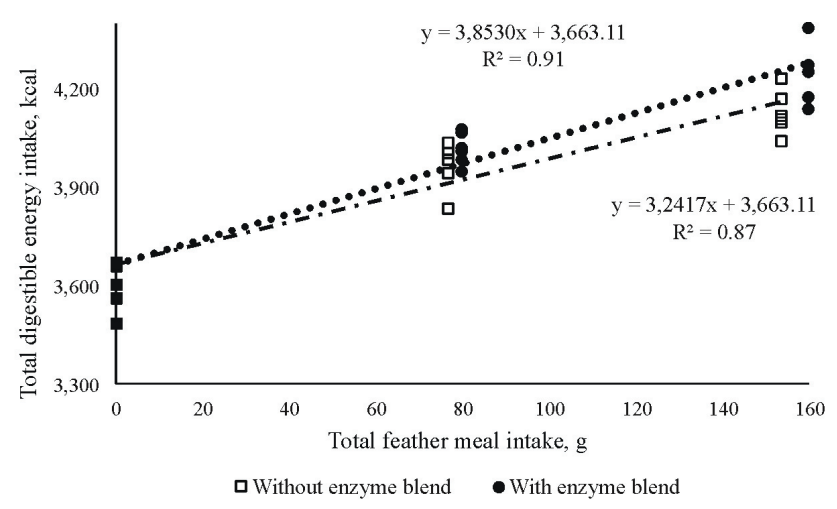

Data represent the comparison between DE slopes of HFM and HFM EB $(P=0.0439)$ DE - digestible energy; HFM - hydrolyzed feather meal; HFM EB - hydrolyzed feather meal with enzyme blend containing protease and lipase.

Figure 2 - Total DE intake of HFM by dogs.

Table 4 - Coefficient of total tract apparent digestibility of nutrients and gross energy and coefficient of apparent metabolizable energy of crude hydrolyzed feather meal (HFM)

\begin{tabular}{lccccc}
\hline Item & CTTADDM & CTTADOM & CTTADCP & CTTADGE & $\begin{array}{c}\text { CM of } \\
\text { GE }\end{array}$ \\
\hline Level HFM & & & & & \\
$\quad 7.5$ & 0.610 & 0.659 & 0.704 & 0.818 & 0.743 \\
15 & 0.605 & 0.694 & 0.656 & 0.626 & 0.490 \\
P-value & 0.944 & 0.631 & 0.147 & 0.001 & $<0.001$ \\
Enzyme & & & & & \\
$\quad$ With & 0.621 & 0.693 & 0.686 & 0.774 & 0.666 \\
$\quad$ Without & 0.595 & 0.660 & 0.673 & 0.670 & 0.567 \\
P-value & 0.729 & 0.654 & 0.677 & 0.039 & 0.040 \\
Level $\times$ Enzyme & & & & & \\
P-value & 0.177 & 0.262 & 0.402 & 0.987 & 0.531 \\
\hline
\end{tabular}

CTTADDM - coefficient of total tract apparent digestibility of dry matter; CTTADOM - coefficient of total tract apparent digestibility of organic matter; CTTADCP - coefficient of total tract apparent digestibility of crude protein; CM of GE - coefficient of metabolizability of gross energy.

${ }^{1}$ Level of addition of the basal diet. 
feather meals are composed of protein and fat. Also, in spite of ether extract digestibility not being assessed, possible explanations for part of the energy released must be attributed to the effect of lipase on the feather fat. The effect of fat in the feather meals was observed in a study with poultry (Ahmadi et al., 2008).

The ME of both types of feather meal was not different when regressions were compared $(\mathrm{HFM}=2,450$ and HFM EB $=2,930 \mathrm{kcal} / \mathrm{kg}$ DM). Such low values must be related to the diets that had not been adjusted for the amino acid balance, and this factor may have contributed to the measured values. Once adjusted, the AA balance in diets could be changed. Therefore, for this study, the DE is the best measurement to assess the effect of enzymes on the feather meal.

\section{Conclusions}

The present study suggests that hydrolyzed feather meal processed with addition of the enzyme blend may be considered an alternative to improve the feather meal quality and use it as a source of protein in diets for adult dogs. The enzyme does not produce improvement in the fecal score, but is under the expected scores for dogs.

\section{Acknowledgments}

The authors gratefully thank the financial support provided by Conselho Nacional de Desenvolvimento Científico e Tecnológico (Brasília, Brazil), and Fundação de Apoio à Pesquisa do Estado do Rio Grande do Sul (Porto Alegre, Brazil).

\section{References}

AAFCO - Association of American Feed Control Officials. 2008. Official Publications of Association of American Feed Control Officials Incorporated. AAFCO, Atlanta, GA, USA.

Adeola, O. 2001. Digestion and balance techniques in pigs. p.903-916. In: Swine nutrition. 2nd ed. Lewis, A. J. and Southern, L. L., eds. CRC Press, Washington, DC.

Ahmadi, H.; Golian, A.; Mottaghitalab, M. and Nariman-Zadeh, N. 2008. Prediction model for true metabolizable energy of feather meal and poultry offal meal using group method of data handlingtype neural network. Poultry Science 87:1909-1912.

Ai, M.; Li, K.; Liu, S. and Lin, D. K. J. 2013. Balanced incomplete Latin square designs. Journal of Statistical Planning and Inference 143:1575-1582.

AOAC - Association of the Official Analytical Chemists. 2005. Official methods of analysis. 18th ed. AOAC, Gaithersburg, MD.

Bertsch, A. and Coello, N. 2005. A biotechnological process for treatment and recycling poultry feather as a feed ingredient. Bioresource Technology 96:1703-1708.
Bielorai, R.; Iosif, B.; Meumark, H. and Alumot, E. 1982. Low nutritional value of feather-meal protein for chicks. The Journal of Nutrition 112:249-254.

Bongaarts, J. 2009. Human population growth and the demographic transition. Philosophical Transactions of the Royal Society B 364:2985-2990.

Case, L. P.; Daristotle, L.; Hayek, M. G. and Raasch, M. F. 2011. Carbohydrates. p.13-79. In: Canine and feline nutrition: A resource for companion. Animal Professionals. 3rd ed. Case, L. P.; Daristotle, L.; Hayek, M. G. and Raasch, M. F., eds. Mosby, Maryland Heights, MO.

Cavalari, A. P. M.; Donzele, J. L.; Viana, J. A.; Abreu, M. L. T.; Oliveira, A. L. S.; Freitas, L. S.; Pereira, A. A. and Carciofi, A. C. 2006. Determinação do valor nutritivo de alimentos energéticos e proteicos utilizados em rações para cães adultos. Revista Brasileira de Zootecnia 35:1985-1991.

Chiba, L. I. 2001. Protein supplements. p.803-837. In: Swine nutrition. 2nd ed. Lewis, A. J. and Southern, L. L., eds. CRC Press, Boca Raton, FL.

Considine, M. J. 2000. New enzyme technologies for poultry by-products. Australian Poultry Science Symposium 12:163-165.

Grazziotin, A.; Pimentel, F. A.; Jong, E. V. and Brandelli, A. 2006. Nutritional improvement of feather protein by treatment with microbial keratinase. Animal Feed Science and Technology 126:135-144.

Jeong, Y. D.; Lee, S. H.; Park, C. S.; Cho, S. B. and Park, S. K. 2015. Variation in coefficient of total tract apparent digestibility of dry matter, nitrogen, and phosphorus and coefficient of total tract standardized digestibility of phosphorus in different corns fed to growing-finishing pigs. Animal Feed Science and Technology 201:66-71

Johnson, M. L.; Parsons, C. M.; Fahey Jr, G. C.; Merchen, N. R. and Aldrich, C. G. 1998. Effects of species raw material source, ash content, and processing temperature on amino acid digestibility of animal by-product meals by cecectomized roosters and ileally cannulated dogs. Journal of Animal Science 76:1112-1122.

Kim, W. K. and Patterson, P. H. 2000. Nutritional value of enzyme - or sodium hydroxide - treated feather from dead hens. Poultry Science 79:528-534.

Kosińska, A.; Chavan, U. D. and Amarowicz, R. 2006. Separation of low molecular weight Rapeseed proteins by RP-HPLC-DAD - a short report. Czech Journal of Food Sciences 24:41-44.

Laflamme, D. P. 1997. Development and validation of a body condition score system for dogs. Canine Practices 22:13-18.

Murray, S. M.; Patil, A. R.; Fahey Jr., G. C.; Merchen, N. R. and Hughes, D. M. 1997. Raw and rendered animal by-products as ingredients in dog diets. Journal of Animal Science 75:2497-2505.

NRC - National Research Council. 2006. Nutrient requirements of dogs and cats. Natl. Acad. Press, Washington, DC, USA.

Pedersen, M. B.; Yu, S.; Plumstead, P. and Dalsgaard, S. 2012. Comparison of four feed proteases for improvement of nutritive value of poultry feather meal. Journal of Animal Science 90:350-352.

Rebafka, F. P. and Kulshrestha, A. 2009. Adding value to feather Goldmehl: A new potential for the petfood industry. Available at: $<$ http://www.petfoodindustry.com/uploadedFiles/PetfoodIndustry/ Articles/1003PETnovel\%20feather\%20meal.pdf.>. Accessed on: Dec. 20, 2012.

Ssu, K. W.; Brumm, M. C. and Miller, P. S. 2004. Effect of feather meal on barrow performance. Journal of Animal Science 82:2588-2595.

Sulabo, R. C.; Chiba, L. I.; Almeida, F. N.; Brotzge, S. D.; Payne, R. L. and Stein, H. H. 2013. Amino acid and phosphorus digestibility 
and concentration of digestible and metabolizable energy in hydrolyzed feather meal fed to growing pigs. Journal of Animal Science 91:5829-5837.

Tiwary, E. and Gupta, R. 2012. Rapid conversion of chicken feather to feather meal using dimeric keratinase from Bacillus licheniformis ER-15. Journal of Bioprocessing \& Biotechniques $2: 1-5$.
Yin, Y. L.; Huang, R. L.; Zhang, H. Y.; Chen, C. M.; Li, T. J. and Pan, Y. F. 1993. Nutritive value of feedstuffs and diets for pigs: I. Chemical composition, apparent ileal and faecal digestibilities. Animal Feed Science and Technology 44:1-27.

Wang, X. and Parsons, C. M. 1997. Effect of processing systems on protein quality of feather meals and hog hair meals. Poultry Science 76:491-496. 